\title{
The duty to be generous (karam): Alternatives to rights-based asylum in the Middle East
}

\author{
Lecture on Africa, Asia and the Middle East \\ read 14 March 2017
}

\section{DAWN CHATTY}

Fellow of the Academy

Abstract: The international standard of providing protection to a category of people who have crossed state borders and fit the legal definition of 'refugee' is a rightsbased construction fashionable in public discourse at present. Middle Eastern constructions of duty-based obligations to the guest, stranger, and person-in-need are, however, less well understood. This article explores the disconnect between international rights-based protection approaches to refuge and duty-based asylum (karam) commonly accepted in Middle Eastern societies. Returning to an exploration of Marcel Mauss' Essay on the Gift, it asks whether we are abrogating our moral responsibilities when we permit a 'rights-based approach' to asylum to prevail. In other words, when we mainstream 'rights' do we repress our human urge to provide refuge to those in need? Should we perhaps be looking for a more holistic engagement with humanitarian assistance and delivery that brings together a duty-based responsibility with a 'rights-based' approach?

Keywords: refuge, asylum, sanctuary, rights-based protection, duty-based asylum, karam, humanitarian assistance, The Gift

More than 60 per cent of the world's refugees currently huddle along the eastern (and southern) rim of the Mediterranean Sea. These-more than 10 million peopleinclude Palestinians, Iraqis, and now Syrians who have fled violent conflict in their countries over the past century. Providing assistance to these enormous numbers of people has not been easy. Refuge, asylum, and sanctuary in the Middle East have become highly contested notions with many international human rights concepts competing with local and regional understandings. The international legal standard of providing protection to a category of people who have crossed international borders 
and fit the legal definition of 'refugee' is a rights-based hegemonic construction in public discourse at present. Local and regional Middle Eastern constructions of dutybased obligations to the guest, stranger, and person-in-need are, however, less well understood or appreciated in the West.

The international legal definition of refugees are those: who are outside of their country of nationality or habitual residence; who have a well-founded fear of being persecuted because of race, religion, nationality, membership of a particular social group, or political opinion; and who are unable or unwilling to avail themselves of the protection of that country, or to return there for fear of persecution (Article 1A (2) of the 1951 Convention). Those who meet this definition are deemed worthy of our sympathy and have rights enshrined in the United Nations 1951 Convention on the Status of Refugees and its 1967 Protocol. ${ }^{1}$ None of the countries of the Middle East adhere to the 1951 United Nations Convention on the Status of Refugees; and Turkey, which is a signatory of the 1951 Convention and its 1967 Protocol, maintains a geographic reservation which restricts the definition of a 'refugee' to within the European arena. Thus, it is not surprising that these Middle Eastern countries hosting the majority of the world's refugees are often taken to task by Western commentators for not abiding by the United Nations rights-based conventions; while countries who have adopted rights-based legislation host relatively few refugees in comparison.

An alternative notion which this paper explores is the 'duty' approach to providing refuge and asylum, the social and sometimes religious duty to provide hospitality/ generosity to the stranger that is widespread in the Middle East and exists in a 'folk' rendering in many societies. This is best expressed through the institution of karam (generosity/hospitality). Using as case studies the Syrian response to the Iraqi refugee crisis which commenced in 2003 and the Turkish, Lebanese, and Jordanian response to the Syrian refugee crisis which commenced in 2011, this paper explores the disconnect between international rights-based approaches to refuge and the duty-based ones commonly accepted in Middle Eastern civil societies, public culture, and national ideologies. It concludes by asking the question 'Do we abrogate our moral responsibilities when we permit "a rights-based approach" to asylum to prevail?' In other words, when we mainstream 'rights' and expect agencies and international organisations to operate under such a mandate do we repress our universal urge to provide refuge to those in need? Should we perhaps be looking for a more holistic or comprehensive engagement with humanitarian assistance and delivery that brings together both duty and moral responsibility with a 'rights-based' approach?

${ }^{1}$ The full text of the 1951 Convention and the 1967 Protocol can be found at http://www.unhcr.org/protect/PROTECTION/3b66c2aa10.pdf 


\section{BACKGROUND}

In October 1945, at the end of World War II, a United Nations Charter was signed in San Francisco to save future generations from 'the scourge of war'. Yet within a very short period of time, the world community felt that the United Nations Charter did not sufficiently define the fundamental rights to which it referred. A drafting Committee, the Commission on Human Rights, chaired by Eleanor Roosevelt, was formed to prepare what was initially conceived as an International Bill of Rights. The Committee met over two years and finally on 10 December 1948 the Universal Declaration of Human Rights was adopted by the UN General Assembly by a vote of 48 in favour, none against, and eight abstentions. In that Declaration, Article 13 provided the rights of citizens to leave their country and Article 14 declared that everyone has the right to seek and to enjoy in other countries asylum from persecution. $^{2}$

By December 1949 the United Nations High Commission for Refugees (UNHCR) was created by the United Nations General Assembly, thus ending the 'Nanson' Era of the 1920s and 1930s which provided refugees - mainly Russians and later Armenians and Assyrians - with travel documents, thus assisting them to cross borders in the search for work. ${ }^{3}$ With the 1951 Refugee Convention, refugees became differentiated from economic migrants, and their desire for sustainable livelihoods while encamped was overlooked (Long 2013). Until the end of the Cold War the population of concern for the United Nations Agency for Refugees (UNHCR) numbered in single-figure millions. However, by the 1990s the number of people of concern to the Agency had climbed precipitously and hovered around the 35 million figure for about a decade (it is currently at over 60 million). The template for providing protection was based on the encampment model developed, some would argue, from practices initiated during the 2nd Boer War (1900-2) to remove people from areas of conflict and to control their access to food, shelter, and communications with the outside world, thus creating a passive and pliable population for ease of management. Over the course of the following 100 years, camps for the displaced by war were increasingly organised according to this military template.

\footnotetext{
${ }^{2}$ This provision declared that everyone has the right to seek and to enjoy in other countries asylum from persecution. Despite endorsing Article 14, most Western states have since made the process of reaching 'other countries' irregular if not illegal. The growth of the smuggling industry across the Mediterranean is one case in point. See http://www.ohchr.org/EN/UDHR/Documents/UDHR_Translations/eng.pdf ${ }^{3}$ Fridtjof Nanson was appointed the first High Commissioner for Refugees by the League of Nanson in the wake of the massive displacement of peoples after World War I. In1922 he began issuing passports to some of the 800,000 Russians stripped of their citizenship by Lenin the year before. In the 1930s these passports were extended to Armenian, Assyrian, and Turkish refugees.
} 
Such 'camp' approaches to the provision of 'refugee' rights (health, shelter, food, and water) were increasingly at the expense of almost all other rights, including education of children, social security, and sustainable livelihoods (Harrell-Bond 1986, Jamal 2000, Crisp 2003, Crisp \& Slaughter 2009). In the context of the middle-income countries of the Middle East, this 'one size fits all' template for protecting refugees has faced serious challenges in its failure to address the wider social concerns of the displaced. These include the specific socio-historical context of the dispossessed (e.g. Syrians traumatised by 45 years living under a controlling police state, fear of engaging with officials), the behaviour of youth (e.g. the rise of male youth gangs, particularly in camps, and the apparent 'selling and buying' of young refugee women), and a desperate search for sustainable livelihoods (e.g. the selling of camp rations, working illegally). It would seem that the paradigm of the refugee camps as a global humanitarian mechanism needs to be reconsidered in the face of the massive Syrian and, and before it, the Iraqi social disarticulation.

Until 2009, the UNCHR promoted camps globally as the most effective and efficient way in which to provide the 'right to life' to those who were displaced generally by armed conflict. The displaced who avoided entering refugee camps were regarded as 'irregular' (UNHCR 1997). However, with the Iraqi refugee crisis following the invasion of that country in 2003, UNHCR took a long hard look at its policies. It recognised that most Iraqis fleeing into Syria and Jordan had purposively bypassed the camps set up for them and sought refuge and sanctuary, instead, in the major cities. This left the UN agencies and other international aid providers scrambling to make contact and search for alternative ways of providing the basic right to life services enshrined in UN statutes and covenants. A high-level field mission in 2008 resulted in a new set of directives recognising the rights of the displaced to self-settle in urban centres (UNHCR 2009). Applied to the specific Iraqi refugee population in Syria and Jordan, it became a 'gold standard' for UNHCR operations. But lessons learned from the Iraqi crisis (which are discussed in detail below), reaching out and working with the self-settled refugees, have proven extraordinarily difficult to operationalise in the complex Syrian humanitarian crisis. Country-specific innovative measures to assist the self-settled are being tested piecemeal by various agencies (Senior Humanitarian Aid practitioner, personal communications, 2014). Little, if any, attention has been directed to gaining a holistic understanding of the customs, social traditions, public culture, and behaviour of the refugees and their hosts in the Middle East. 


\section{The Iraqi case}

Iraqi forced migrations did not start in the past decade but rather nearly a century before, at the end of World War I. The Paris Peace Conference of 1919 saw the dismantling of the Ottoman Empire and the widespread displacement of groups impacted by the creation of 'mandated' neocolonial states in the region. Over the course of ensuing decades, wave after wave of Iraqis fled their country, following or creating linkages in bordering states that had once been part of the Ottoman Empire. In the years following the 2003 invasion, Iraqis did not flee when expected and then when they did set out into exile, they refused to enter the internationally organised holding camps, choosing to settle on their own in urban centres. Even as one of their host countries, Syria, imploded into spasms of violence and bloodshed, the international community raced to create new holding centres outside the borders with the country. Yet only a few thousand Iraqis moved out of Syria and fewer returned to Iraq. International assumptions regarding refugee behaviour in this part of the world appeared to be unravelling, and a fresh understanding of mobility and the duty to provide refuge, asylum, and hospitality was required.

In March 2003 the US, supported by the UK launched its first set of air strikes on Baghdad. 'Operation Iraqi Freedom' was officially underway. In the six-month build-up to this military venture there had been estimates that a Western military engagement would cause the displacement of more than one million people within Iraq and across its borders. The UNHCR and numerous NGOs made preparations to receive this wave of humanity in Jordan, Syria, and Iran. In Syria, the UNHCR negotiated the upgrading or building of three campsites in eastern Syria and at the border crossing. In Jordan, the UNHCR worked closely with the Hashemite Charitable Society to set up a refugee holding site near its eastern border with Iraq. In addition, the UNHCR stockpiled relief items at the southern port of Aqaba for immediate dispatch should that prove necessary. In Iran, the government's Bureau for Aliens and Foreign Immigrants (BAFIA) prepared ten campsites with the help of the UNHCR.

Despite the dire predictions, few Iraqis fled Iraq in 2003 (Chatty 2003). No Iraqi refugees crossed the border into Iran. In Syria just over 200 Iraqis crossed the border and took refuge at El Hol camp. In Jordan, more than 1,200 refugees arrived at the border crossing between Iraq and Jordan and found themselves trapped, unable to cross over into Jordan and unwilling to go back into Iraq. These were mainly third-country nationals trapped in a 'no-man's land': Iranian Kurds, Iranian Arabs, and Palestinians. Two months after 'Operation Iraqi Freedom' had begun, some 550 Palestinians and a few hundred other Arab refugees were allowed entry into the Jordanian refugee camp at Ruwaishid. 
We now know that between 2006 and 2010 more than one million and possibly two million Iraqis fled the sectarian explosion and general insecurity which descended on Iraq in the years after the Anglo-American invasion (Sommer-Houdeville 2017). These forced migrants largely sought refuge but not 'refugee status' in the neighbouring countries of Syria, Jordan, Egypt, Lebanon, and Turkey. They were mostly middle-class professionals who found their way to the large cities where they could become invisible. Indisputably, Syria hosted the largest number of displaced Iraqis as temporary guests. By 2012, with Syria imploding in armed uprisings and rebellion, many in the humanitarian aid regime expected Iraqis to return to Iraq or to attempt a crossing into Lebanon or Jordan. But again expectations were proven unfounded. Only several hundred Iraqis returned to Iraq. Most hunkered down in the Syriangovernment-controlled urban and suburbs neighbourhoods that had accepted them and had provided them with refuge and hospitality.

Why had estimates of displacement and humanitarian aid needs been so far from the mark? How was the original forecast of one million refugees in 2003 calculated and why was this figure so readily accepted by the humanitarian aid agencies? We now know that in the first few years after 2003 most Iraqis did not cross international borders. Instead most were internally displaced within the country's borders. In 2003 some 300,000 Iraqis were displaced, mainly Arabs who had recently been forced to settle in Kurdish villages surrounding the northern Iraqi town of Kirkuk by Saddam Hussein's regime.

Ten years on and still the international humanitarian aid regime is not getting it right. Expectations of Iraqis returning to Iraq did not come about either in 2003 or in the years since. An expected surge of return from Syria after 2011 resulted in the Iraqi government setting up reception/detention camps on the Iraq/Syria border which were never filled. An International Organization for Migration (IOM) report identified that between 2010 and 2013 a total of 76,000 Iraqis had returned to the country (IOM 2015). Iraqi, Syrian, and other Arab exiles continue to confound international humanitarian aid organisations actors when policy and programming are developed for them within the framework of international rights-based humanitarianism.

The fundamental errors in judgement which have made the Iraqi case so controversial are two-fold: historical and cultural. Anglo-American strategists drawing up a post-invasion plan assumed that the Iraqi people would welcome the invasion and behave as most Europeans would: flee from areas of armed conflict and return when security had been reimposed. This judgement was based on flawed intelligence as well as on an assumption that Iraqis would regard 'Operation Iraqi Freedom' as a liberation campaign by the Anglo-American powers. What was not recognised by these powers was the extent to which Iraqis regarded the Anglo-American campaign as a neocolonial assault on their homeland. Most Iraqis preferred to stand their ground 
and, sheltering among familiar neighbours and kin, safeguarded their holdings, while affirming their Iraqi-ness. The Anglo-American assumption that Iraqis might flee and later return to recover their property and possessions - as guaranteed by international law - was not one that many Iraqis, or any Middle Easterner, for that matter, would make. The historical lessons of Palestine and Palestinian refugees have been deeply engrained in the Middle Eastern social psyche. Witnessing the traumatic catastrophe of the Palestinian Arabs in 1948 when 750,000 fled their homes in the anticipation of returning as soon as fighting in their neighbourhoods or villages and towns stopped, and the decades of protracted displacement and temporariness that followed, in part due to Israeli rejection of their right to return as well as Arab states' unwillingness to permanently resettle them, have contributed significantly to Iraqi migration decisionmaking. If you flee war in your homeland, you may not be allowed to return when fighting ends.

The Iraqi cultural response to dispossession and displacement-one that is beginning to be recognised as more pervasive and widespread globally - has proved to be very much at odds with international expectations of the behaviour of the 'model' refugee who seeks out and succumbs to the ministrations of humanitarian aid as manifested in prefabricated and rigidly administered holding camps. Sites of 'bare life', where all agency and self-sufficiency are stripped away and the refugee enters a liminal status between citizen and outcast, is a fair description of contemporary internationally sanctioned and operated refugee camps (Agamben 1998).

\section{The Syrian case}

The current displacement from Syria inevitably follows the pathways of Iraqi and Palestinian refugees before them (Marfleet and Chatty 2009). Those movements and occasionally return migrations have changed social identities and notions of belonging and reshaped both host societies as well communities of origin (Chatelard 2010, Chatty \& Lewando-Hundt 2005, Van Hear 1998). Regarded as temporary guests rather than 'refugees' by their hosting authorities, some have become part of 'neardiasporic' communities while others have integrated or created new identities and ties of belonging to a reshaped host society (Cohen 1997, Vertovic 2001). In Lebanon the impact of flows of displaced people both internally and from across its borders is seen as a threat to an already weak and brittle public sector. Turkey, on the other hand, perhaps with important international relations goals, has set up a system of temporary protection and refugee assistance of a standard far superior to any achieved in the region by the international humanitarian aid regime.

UN estimates are that over 85 per cent of the Syrian refugee flow across international borders is self-settling in cities, towns, and villages where they have social networks. 
In other words, only $10-15$ per cent of the Syrian refugee flow is into camps. This includes 25 non-UN camps in Turkey, three UN camps in Jordan and none in Lebanon (ECHO 2015). Overall, there has been a general rejection of 'encampment' by most Syrians in Jordan and in Lebanon; while in Turkey the response is more complex (Kirisci 2013).

By August 2016, about 15 per cent of the approximately 2,800,000 Syrian refugees in the country actively sought out the 'non-standard' camps managed by AFAD, the Turkish Disaster Relief Coordination Institution under the Office of the Prime Minister. These camps have been described as 'five-star' by international experts (International Crisis Group 2013); some have cynically suggested that such a model cannot be sustained as it is too expensive in the long term. These Turkish camps do much more than give food and clothes; most camps have classrooms, hospitals, areas for recreation, sports, and religious worship, laundry and television rooms, meeting tents, and even hair salons. They do not conform to the 'camp' template designed by the UNHCR; rather they take on the appearance of small towns. More than any other feature, they are open access and provide their residents with opportunities to come and go.

In contrast, in Jordan, an estimated 600,000 Syrians flooded into the country over a short period of time. This led to fears in some quarters that these refugees would destabilise the country if they continued to disperse and self-settle throughout the country. The Jordanian government then abandoned its laissez faire policy and determined that all newly arriving Syrians would be placed in UN-sponsored camps. Thus, new arrivals after the summer of 2012 have been rounded up by the Jordanian army as they crossed the border and handed over to the IOM for processing and entry into the UNHCR border camps at Zaatari and at Azraq.

In Lebanon, an estimated 1,100,000 Syrians have crossed the border and are self-settled in thousands of small units throughout the Bekaa Valley and along the coastal cities of the country, making standard humanitarian relief mechanisms hard to deliver. The international aid regime has persisted in recommending the establishment of formal official refugee camps in the country. But these requests have been consistently rejected by the government (White et al. 2013).

From all three of these countries there is much to be learned not only about dignity in exile and refugee protection, but also about the nature of local and regional notions of hospitality, sanctuary, and refuge, identity and belonging as well as how social capital and networks emerge in the hosting community. Although under-researched, historical examples in the Middle East do show that successful 'near-diasporic' resettlement or return are clearly associated with the manner of reception and accommodation of exiles and forced migrants in host communities (Chatty 2010, Loizos 1999, Shields 2016). 


\section{OTTOMAN LEGACIES, ARAB CUSTOMS, AND PUBLIC CULTURE}

\section{The Ottoman legacy of mobility and migration}

The end of World War I saw the collapse of the Ottoman Empire and its dismemberment along lines proposed in several secret wartime agreements undertaken by the French, British, and Russian governments. The Sykes-Picot Agreement as well as the Balfour Declaration set out the neocolonial borders of the southern region of the Ottoman Empire. However, even prior to this final collapse, the Ottoman state had been pushed to accommodate the dispossession and forced migration of millions of its subjects within the Empire. This was a response to failed attempts to repulse competing claims to borderlands largely from Tsarist Russia which forced the creation of an independent Bulgaria, Serbia, and Romania out of the European Ottoman Empire. And in the process, as detailed by Justin McCarthy, the Russians dispossessed and ejected the native populations of Circassia and Abkhazia in the Caucasus, forcing the Ottomans to take in more than 800,000 Caucasian peoples. A further 900,000 Turks were also forced by the Russians into the Ottoman Empire which then had to find food and shelter for them when the existing population was already poor (McCarthy 2001).

By 1857 the Sublime Porte in Constantinople (Istanbul) set out a code of conduct to deal with this mass influx of refugees and migrants. This was the Refugee Code to welcome refugees and migrants into the Empire. Three years later, a Refugee Commission was established (1860) to facilitate refugee settlement in, first, the Ottoman Europe (the Balkans) and then later, near the end of the 19th and early 20th century, in the southern provinces of the Empire-Anatolia and Greater Syria (Chatty 2010: 97). The Commission oversaw the management of international aid-mainly missionary - coming into the Ottoman Empire. But, more importantly, it set a precedent for how to receive and best integrate refugees, exiles and migrants alike. It coordinated in-country aid and the feeding, clothing, and sheltering of several millions of refugees as they progressed through and near cities to eventual sites where they were encouraged to settle. There were no internment or holding camps. Rather than trying to provide basic emergency aid in a fixed location, the Ottoman state encouraged local communities to assist this flow of humanity and to provide hospitality to their largely Muslim 'brothers' and 'sisters'. In addition, the state set out incentives for self-settlement. Forced migrants who turned into settlers were provided with up to 17 acres of land to start farming. They were provided with seeds, draft animals, and money to buy farm equipment. They were expected to build their own houses - often in the style of their original homeland - or to get local people to build for them. They were prohibited from selling their new land holdings for fifteen years in an effort to make sure that local investors and entrepreneurs did not take advantage of these new 
settlers and in order to give these newcomers time to adapt and acclimatise (Chatty 2010: 98). Until 1878 forced migrants were largely settled in rural areas. Only later did the Ottomans commence the construction of new migrant districts in the neighbourhoods of towns and cities - the Muhajirin district of Damascus, for example, was first established to house the forced migrant settlers from Crete in the late 1890s.

The Paris Peace Conference at the close of World War I resulted in the British gaining the League of Nations mandate administrations over the Kingdom of Iraq (former Ottoman regions of Basra, Baghdad, and Mosul) and the French being granted the mandate authority over Greater Syria (modern Syria and Lebanon) in 1920. These mandates were not locally popular and uprisings, rebellion, and armed conflict greatly marred their authority. The Arab Revolt of Syria (1925-7) drew in large elements of the country's population. When the British gave up their mandate of Iraq in 1932 after a decade of battling local insurgencies, they left behind their Assyrian supporters who had worked with them as gendarmeries. Thus the first massive wave of Assyrians fled Iraq for Syria, Lebanon, Turkey, and the West.

In French-mandated Syria, refugees continued to flow into the country from Iraq, from Turkey, from Palestine, as well as from the Balkan states of Albanian, Bulgaria, and the Caucuses. These newcomers were granted citizenship. Although there was some disquiet in a few intellectual corners at the idea of Armenians, Assyrians, and Kurds becoming citizens in a country which was largely Arabic speaking, this disgruntled attitude gave way to muted appreciation of many of these minority social groups who took part in the country-wide demonstrations against the continued French neocolonial grip over the state throughout the 1920s and 1930s (White 2004, 2011). The modern nation state of Syria was rapidly becoming a country of minorities sharing notions of local cosmopolitanism and conviviality (Chatty 2010, 2013, Rabo 2008).

\section{The Ottoman millet}

What was remarkable about the Ottoman Empire was the way that its organising ethos was not based on ideas of ethnic superiority of one community over another but rather on religion. Belonging was tied to social places rather than physical spaces. In other words, the Ottoman subjects recognised the superiority of Islam in the Empire, but were also cognisant of its tolerance of the Ahl-il-Kitab-its Jewish and Christian communities. This acceptance was based on religious tenets as well as economic and political realism. European mercantile interests in the Christian and Jewish communities in the Middle East as well as Ottoman principles of self-governance for these ethno-religious groups resulted in the establishment of protected communities, millets whose religious and social affairs were organised from within the structured 
and specific mechanisms of the church or synagogue. ${ }^{4}$ It was the legacy of these 'millets' that shaped the way in which the great forced migrations of the 19th and 20th centuries were absorbed into the fabric of the societies and cultures of the Middle East.

The term millet (which comes from the Arabic milla, a religious community or denomination) originally meant both a religion and a religious community. The Ottomans regulated and institutionalised the millet system in the 19th century. Thus, Muslims, for example, might be ethnically and linguistically Turks, Arabs, Kurds, Albanians, Bosnians, Circassians, and others. Jews, especially in the northern provinces were mainly Sephardic, the descendants of those who had been given refuge after being expelled from Spain and Portugal in the 16th century; but there were also many Mizrahi, or Oriental Jews. The Christians were mainly Orthodox and comprised Greeks, Serbs, Bulgarians in the Balkans, and Arabs in Palestine and Syria (McCarthy 2001). In some areas, ethnic groups were fairly homogenous. In others they were widely dispersed. Constantinople in the late 1800 s was a mix of ethno-religious minorities. But records only identified religious or millet affiliation. At the end of the 1900s Constantinople was 56 per cent Muslim, 22 per cent Greek Orthodox, 15 per cent Armenian, and 4 per cent Jewish. While Muslims were a large majority in the Asiatic provinces, and a significant one in the European areas of the Empire, most regions had significant Christian and Jewish minorities. Few non-Albanians, for example, lived in Albania. But there were Muslim, Catholic, and Orthodox Albanians. Ethnically, most of west and central Anatolia was Turkish; the southeast was Kurdish; while the Levant and Arabia were mainly Arab. Yet these regions also had significant religious 'majorities' and 'minorities': Muslim, Christian, and Jewish adherents. In many other areas there was a thorough mix of ethnic groups and religious affiliations. Sometimes it was villages of one ethnic group or religious affiliation adjacent to another ethnic group or religious affiliation. In some cases, single villages and small towns had a number of ethnic and religious groups. Thus it was impossible to manage these widely dispersed peoples on the basis of territoriality. And at the same time, ethnic and culturally similar linguistic groups were establishing wide-ranging networks of ethno-co-religionists throughout the Empire. As Argenti elaborates, a sense of shared existence between neighbours of different cultural and religious backgrounds characterised the 'peace that reigned over Anatolia' and the southern provinces for so much of the Ottoman Empire (2017: 10).

\footnotetext{
${ }^{4}$ The term millet was used by the Ottoman administration to identify and designate Ottoman nonMuslims. It dates back to the reign of Sultan Mahmud II (1808-39). Before the 19th century the term meant Muslims within the Empire and Christians outside it (Quataert 2000: 173).
} 
The late 19th and early 20th centuries left a profoundly negative mark on the history of human settlement and political engineering. The Ottoman Empire, which had developed a largely successful multicultural and religious pluralism, was gradually dismantled by pressures from within as much as from outside. This demise came quickly, although it was prefixed by a nearly century-long reweaving of the peoples of the Balkans, eviction of the Muslim peoples in the Caucasus, and the remixing of the largely Muslim peoples in Anatolia with the departure of the Orthodox Greeks and Armenian Christians. The numerous forced migrations that accompanied this era are too complex and also too contested to be dealt with adequately here in this paper. However, it may be enough to say that this upheaval saw an entire Empire on the move. Furthermore the deterritorialised aspects of belonging tied to the Ottoman ethno-religious millets laid the foundations for later elaborations of migrations, mainly circular and back-and-forth between relations, co-religionists, colleagues, customers, and creditors in the modern Arab successor states of the Empire.

The Empire's century-long struggle against collapse saw the rise of numerous nationalisms followed by short-term movement and large-scale migration within its borders. Several million people were uprooted between about 1875 and 1925 from the Balkans, or more specifically Bulgaria, Macedonia, Thrace, and western Anatolia. These forced migrants found their way to Anatolia and further south to Syria, Lebanon, Jordan, and Egypt. Armenians in the heartland of Armenia also moved into the Syrian provinces, and to Egypt where they found long-settled co-religionist communities. Kurds, Palestinians, and Circassians and Chechnyans were also spread throughout the southern provinces of the Empire in a combination of forced and voluntary migrations throughout the 19 th and 20th centuries. The unmixing of peoples initially followed religious rather than linguistic lines. The Muslims moved south and east, and the Christians moved north and west. Thus, it was not only ethnic Turks who retreated towards Ottoman core areas, but also other Muslims, notably Bulgarians and Bosnians, as well as Circassians and Crimean Tatars who had fled earlier from Russia to the Ottoman Balkans. These movements, some for trade and others the result of nationalist struggle and war, created a carpet of locally cosmopolitan and migratory communities in the Middle East in the aftermath of the collapse and carving up of the Ottoman Empire at the end of World War I.

The Ottoman Empire was remarkable for having 'uncoupled the essentialised relationship linking ethno-religiously defined peoples to places' (Argenti 2017: 9). These dispossessed Ottoman peoples took with them the memory of a multi-ethnic and multi-religious empire as well as the singular remembered and partially imagined homelands where culturally distinct peoples would nevertheless form an interdependent social whole. Over the next few decades, two further peoples were to become dispossessed and forced from their homelands or have their lands politically transformed 
underfoot: the Palestinians and the Kurds. Their dispossession has added to the region's cultural experience of movement and forced migration and plays an important contemporary role in the networking and migration decision-making of the current wave of dispossessed and displaced Iraqis and Syrians.

\section{Legacy of the millets, notions of solidarity, and hospitality}

In 2004 Human Rights Watch observed the situation around Kirkuk where some Iraqi populations were fleeing and others were returning. They reported that:

Much of the Arab population brought to the rural areas in the north during the Arabisation campaign [of Saddam Hussein] fled during the war. ... Human Rights Watch is not aware of a single massacre committed against Arab settlers by returning Kurds or other minorities. This is an experience vastly different from that of the Balkans, where bloodshed was routine during the various 'ethnic' cleansing campaigns that characterized those conflicts (Human Rights Watch 2004).

During the past five years of the armed conflict in Syria, there has been little 'ethnic cleansing of minorities' of the sort seen in the Balkans, though some might argue that Homs has been ethnically cleansed of its majority Sunni population by the Asad regime along with other specifically targeted sites. In general, relations between displaced, host communities, and returning groups were not what the humanitarian aid regime was expecting based on its experience in other continents and contexts. One explanation for this resistance to conducting 'ethnic' cleansing may lie in the historical antecedents of ethnic tolerance in the immediate region, a legacy of the millet system. But it may also be explained by reviewing the nature of group solidarity and concepts of generosity and hospitality in the Arab world.

The Arab expression 'I against my brother; I and my brother against my cousin; I, my brother and my cousin against the world' perfectly describes the layered outlook on alliances and enmity among families, lineages, and tribes throughout the Arab world. Though largely regarded as a form of organisation exclusive to the Arab Bedouin tribes, it is the segmentary nature of alliance and network building on the basis of real or fictive kinship which extends to urban folk as well. Generally, the members of a recognised social unit support each other generously, take in its members when moving from place to place, and often make migratory moves together-both forced and voluntary. Expulsion of an individual in the modern political context of Iraq and its neighbours often means moving the entire extended family. Thus, individuals had a large group to rely on and the whole group had each other to rebuild lives shattered by politics or conflict.

The unit was often represented by a leader, generally the strongest and most charismatic male of the extended family group or lineage. This leadership was also 
vested in a moral authority which could be augmented or lost by behaviour which either respected or disregarded family norms and custom, particularly with regard to generosity and hospitality (Chatty 1977). One could argue that the Asad regime relied on developing much the same authority built on 'acts' of public generosity to the nation, such as commissioning statutes of President Asad outside of football stadiums, libraries, opera houses, and other monumental projects. The citizens then reacted to this 'politics of public dissemination' by acting as if they revered their leader (for more detail see Wedeen 1999). Karam, the Arabic term which can be translated as hospitality or generosity, is ultimately also about security, protection, and respect. The family or lineage's reputation is in many ways hostage to correct behaviour with a guest/stranger, as inappropriate behaviour might lead to disrespect, danger, and insecurity (Shryock 2004). With identity and security based on family, lineage, and ethno-religious millets, movement did not represent a decoupling, or deracination, but rather a wide horizontal network of support and solidarity. Relatives, close and distant, were spread over a wide region far beyond the confines of the modern nation state and could be called on for support, shelter, and security when needed. In the case of Iraqi refugees entering Syria, the Asad regime adopted the role of the 'paterfamilias' of the nation, extending 'hospitality' to the Iraqi refugees as a moral duty rather than as a rights-based act derived from international law. ${ }^{5}$ Another term commonly used in the Middle East with respect to providing hospitality to the stranger is thawaab (merit, or duty, or correct behaviour). Its religious overtones refer to collecting merit by good behaviour for the Day of Judgement. Variants of the term exist in Turkish, and also in Persian.

Notions of hospitality and generosity and the ways in which such acts augment individual and family honour are fundamental to an understanding of many societies and cultures (some of these notions are rooted in Ancient Greek philosophy, as illustrated in the treatment of the stranger and exile in The Iliad and later The Odyssey). They are also developed in Kantian Ethics where the duty 'to do good' is primordial. Perhaps the universality of this 'moral economy' is best articulated in Marcel Mauss' Essay on the Gift, a seminal study of gifting (providing hospitality) based on ethnographic and historical records of the time. Mauss' short but magisterial work explored alternatives to the modern capitalist economy in the wake of the most brutal and destructive war-World War I - that had yet been experienced by mankind (Mauss 2016 [1925]). His detailed ethnography reveals that the practice of gifting has not disappeared in industrial society (though we may not recognise it). And that, as with karam, gifting creates a relationship and requires a return. Excessive gifting or inappropriate return can result in hostility and insecurity. The practice of gifting,

${ }^{5}$ I do not wish to make the association that the state opened its borders as an act of national generosity. Instead, I would suggest that the regime was cynically using the language of individual acts of generosity for its own security purposes and perhaps also to benefit from international humanitarian assistance. 
according to Mauss, is often found among the 'masses' (host communities) who have evolved a better sense of the 'general interest' of society and express it in mutuality and solidarity. The Essay, thus, is an implicit and explicit assessment of how generosity/ hospitality and the duties and obligations are kept alive in many societies and might also be kept alive in Europe. It is Mauss' conviction that deep attentiveness to human exchange - material, intellectual, moral, and spiritual - might give life to post-war recuperation from the tragedies and travesties of war for which 'we must weep' (Mauss $2016[1925]: 11)$.

\section{Hospitality redefined in Western rights-based practices}

The notions of generosity and hospitality, of mutuality and solidarity are particularly redolent in the Middle East. In many Western countries, however, 'hospitality' has become a dominant notion in legislated asylum and immigration practices built upon international legal obligations. It is used in official discourse and in social analysis and is found in such fundamental terms as host country, reception centres, and asylum hotels (Rozakou 2012: 562). However, tension and perhaps even a transformation in the moral economy of Europe - the traditional view of social norms and obligationshas resulted in growing tensions between the discourse and practices of compassion and legally framed repression as highlighted in the deportation dramas at Sangatte in 2002 (Fassin 2005) and the 'Jungle' at Calais in 2016. How is it, Michael Herzfeld asks, that 'in contemporary societies justly famed for their hospitality and warmth, we often encounter the pettiest form of bureaucratic indifference to human needs and suffering' (1992: 142)? Is this a response to the 'mainstreaming' of the 'rights' of refugees and asylum seekers in the West which results in a growing depoliticisation and disinterest in active moral response or responsibility? In another context, it has emerged very clearly in recent scholarship that mainstreaming of 'gender' in international and non-government agencies has resulted in a lack of interest or sense of responsibility for 'gendering' in internal policy and external programming (Pialek 2008).

It may be that in the face of such mainstreaming of 'rights' of refugees in Europe a form of mutuality and solidarity as identified by Mauss is gradually emerging to resist the political reframing of 'social duty' into 'rights-based law'. In France and now also in the United Kingdom, Germany, and Sweden a call for civil action paralleling (or resisting) state positioning is developing in public culture. ${ }^{6}$ The seeming

\footnotetext{
${ }^{6}$ For example, in the UK, voluntary groups such as Rural Refugee Network are active in supporting Syrians once they arrive in the country and helping to place them with local families; in Germany a refugee charity, Willkommen, was set up in the Hamburg train station to orient refugees as they arrived; and in Sweden a movement called VI STÅR INTE UT ('We can't stand it anymore') is growing among professional people and others who are protesting against the inhuman treatment of refugees.
} 
growing indifference in state regulations in Europe and the UK to moral obligations to refugees and asylum seekers in the face of extraordinary suffering appears to be changing. Fassin, in his explorations of moral anthropology asks why in societies which have become hostile to asylum seekers and immigrants does there remain 'a sense of common humanity collectively expressed through attention paid to human needs and suffering' (2005: 366). The recent French moves to regulate and control hospitality and criminalise those who offer succour to the illegal immigrant or refugee are seen by some as an attempt to impose official rights-based law (bureaucratic indifference) on everyday life.

Yet public discourse in France has resulted in a plea among some intellectuals to redefine hospitality and refocus attention on human need and suffering. This group refers to the French 'myth of hospitality' and calls for remission of these rights-based laws. It argues for the need to have both an ideal, national policy based on rights of categories of people but also to recognise and permit the private engagement of individuals based on a sense of moral duty and obligation (Fassin 2005). This movement calls to mind Derrida's 'Law of Hospitality' which refers to absolute and unconditional hospitality in contrast to the French efforts to legislate a 'pact of hospitality' (Derrida and Dufourmantelle 2000). The latter, clearly derived from Mauss' seminal essay, is conceptualised as a contract that specifies rights-based rules and duties of the guest and the host. These then are spelled out in asylum and immigration laws of the state as well as in practices of humanitarian actors in receptions, centres, refugee camps, and holding centres. The former relates to the idealised norms and obligations of compassion for humanity which drive a local community-based effort to provide sanctuary to these needy 'guests'.

A similar discourse has existed in the United Kingdom, where the accommodation of asylum seekers in immigration centres, or 'asylum hotels' has been in public debate for most of the past decade. Britain has a mythology of hospitality 'to those fleeing from political and religious persecution' (Cohen 1994: 72). The accommodation of strangers, particularly 'neighbours' from the Continent, has long been part of normal social conventions of hospitality and one might say a customary legal right: Belgians in the 1940s, Hungarians in the 1960s, and Bosnians in the 1990s. But hospitality to the more distant stranger is another matter. After several years of inertia, challenges to the country's rights-based determinations regarding who among refugees and asylum seekers may benefit from the state is emerging. Local civil society (as well as local councils) efforts to set into motion forms of support and sponsorship for refugees from Syria as well as other acts of moral clarity are on the rise (see, for example, the work of the British Rural Refugee Network based in Hampshire http://www.ruralrefugeenetwork.org).

Yet, the impulse to be hospitable has come to be separated all over Europe from the granting of asylum. The latter is an act which the host state or nation can 
engage in within the framework of political laws and the limited protections set out in international law. The former is an individual social act associated with generosity and 'gift-giving' and is more in the realm of moral justice. Accommodating strangers in the UK is no longer an act of individual generosity, but rather a political act of hospitality which can easily elide into hostility. The current detention of asylum seekers fleeing political persecution is the phenomenon which this calls to mind. The collapsing of hospitality to the stranger which is often accompanied by growing hostility emerges from the conditionality set by the state structure. As Derrida argues, a distinction has emerged in the West between the ethics of hospitality (as cultural norm) and the politics or law of hospitality which reigns conditionally. No nation state in Europe would unconditionally open its doors to strangers. Absolute hospitality would undermine the very condition of the nation or state (Derrida and Dufourmantelle 2000). If this argument were to be followed to its logical conclusion, then the nation's hospitality would be based on the assumption that the national space could be conceived of in terms of hosts and guests, the nation as a house in which hospitality could be offered and received. In the liberal democratic states and constitutional monarchies of Europe this would simply not be possible without undermining the sovereignty of the nation. In the authoritarian and constitutional monarchies of the Middle East, however, this is exactly what is developing; hospitality to the stranger is both a national as well as an individual act.

Contrary to the dominant discourse on refuge and hospitality in the West where asylum seekers are placed in a liminal space in state-run detention centres and camps (Agamben 1998) and denied full social existence as a member of a nation state, I am arguing here that the notions of hospitality and generosity are so important in Middle Eastern cultures as to make it nearly impossible for the state to adopt international refugee law which seems to carry with it the 'pettiest form of bureaucratic indifference to human needs and suffering' which Herzfeld identified (1992). National or domestic asylum laws are not part of the legislation of most countries of the Middle East largely because hospitality to the stranger is deeply rooted in notions of individual, family, and group reputation. Public culture around the generosity of the father figure ruler (monarch or dictator, it doesn't matter) is significant. The state is seen as the family which is hospitable to the stranger. Providing hospitality/asylum increases one's reputation for generosity. The setting up of 'halfway' houses or state facilities, as well as international humanitarian holding camps, becomes unnecessary if not repugnant. ${ }^{?}$

\footnotetext{
${ }^{7}$ The Palestinian refugee case is particularly complicated as it was not at its core an issue of refuge or asylum. Rather it was fundamentally a rejection of the unilateral ending of the British Mandate and the revocation of all citizenship rights of Muslim and Christian British Mandate citizens, but not Jewish British Mandate citizens.
} 
In the Middle East the idealised understanding of the state is that it, the state, is the 'host family', and that the actual acts of hospitality are a matter for the local community and the private individual to enact as a private act or via the church or mosque or other charitable organisation. In Jordan, Lebanon, and Turkey, local 'coexistence' initiatives have emerged that are bringing together refugees from Syria with local hosting communities. These local and regional associations set up both by resident Syrians and by nationals now dwarf the measures put into place by the international humanitarian aid regime (Syria Regional Refugee Response 2016). In Jordan, for example, Generations for Peace works to smooth out relations between refugee youth and local youth. In Lebanon, a Syrian-founded and organised NGO, Sawa4Syria undertakes to help Syrians empower themselves and 'take control of their present and their future'. While in Turkey, despite tight government control and restrictions on the activities of IGOs and NGOs, civil society local initiatives are emerging to provide various forms of hospitality for Syrians, such as Ala Syria, which work towards developing skills among the youth for their eventual return to Syria. Studies of refugee reception in exile have not yet considered the impact which generous accommodation and access to skills training and education facilitate may have on local integration and, in some cases, successful reintegration to places of origin (Chatty et al. 2014, Sirriyeh 2016).

The refugee camp as a reception centre is not part of Middle Eastern positionings with regard to the stranger. The forced migrant is welcomed or tolerated as a guest, generally temporarily but sometimes of long duration. The ideal of an 'Arab nation' persists in the rhetoric and the practices of some Arab states. Syria, for example, practised a near unconditional hospitality which saw it permit all Arabs into the country without visas. ${ }^{8}$ Other Arab states have less rigid visa requirements for entry of Arabs compared to entry of other 'foreign nationals'. Only pressure from the international community and, in particular, the UN Agency for Refugees in the period after the mass influx of Iraqis into the country saw the imposition of a temporality to its hosting-Iraqis could get a three-month entry visas at the border on application. These restrictions were later relaxed and one-month visas at the border were reinstated, with renewal in country common.

Middle Eastern notions of hospitality assume that the national space can be conceived of in terms of the host and guest. The nation becomes a house or home in which hospitality can be offered and received. A relationship of power, as first articulated by Mauss, is implicit in Derrida's neologism of hostipitalité; hostis connects the figure of the stranger and host while potis calls up the semantics of power and sovereignty. In this sense the host is thus someone or something which has the power to give

${ }^{8}$ Bahrain, in earlier decades, received Omani exiles unconditionally and educated an entire generation before their return to the Sultanate of Oman in the 1970s. 
to the stranger [generosity] but remains in control (Derrida 2000, Mauss 2016 [1925]). This provides a clear philosophical fit with the Arab notion of karam [generosity/ hospitality] and the network of solidarity and support which it can engender. The widely used popular expression 'bayti, baytak' (my home is your home) or even 'watani, watanak' (my country is your country) perfectly exemplifies the notion of the host who has the power to provide generosity to the stranger/guest and who retains that power. The act of hosting does not diminish that power. On the contrary it enhances the karam and thus the reputation of the host. In addition, the act of hosting creates greater security by enlarging the network (wasta) of the host and at the same time manages hostility. One day the host may become a stranger somewhere and seek hospitality/refuge, thus setting into motion a reciprocal cycle of hospitality and refuge among members of different millets which are the antecedents to the modern Arab nation states in the Middle East.

\section{CONCLUSION}

Iraqi and Syrian exiles and refugees have regularly confounded the international system of humanitarianism. Iraqis did not flee their country when expected to nor did they return in the numbers expected after 2011. They have eschewed the holding centres and containment camps set up for them on barren border lands and sought refuge, sanctuary, and hospitality from their Arab hosts in populous localities and urban centres. The Iraqi rejection of camps caught the international community off guard and has since resulted in a rethink at UNHCR and other refugee agencies. Only a few years ago, refugees who evaded camps were 'criminalised' for such acts. However in 2009, largely as a result of the Iraqi crisis, UNHCR issued new guidelines to address the bureaucratic requirements for effectively dealing with the urban, self-settled refugee. Displaced Syrians have also largely avoided the holding centres and camps set up for them in the region and instead sought out self-settlement and opportunities for local accommodation and integration. But the Syrian numbers are gigantic compared to those from Iraq. Whereas the one million or more Iraqis found hospitality regionally, Syrian numbers overwhelmed the hosting communities. With 10 per cent of the population of Jordan made up of refugees from Syria, and 30 per cent of the population of Lebanon made up of displaced Syrians, it is no wonder that the 'house' has become full and some of those seeking asylum have had to look further afield to the northern shores of the Mediterranean. This one might say is what happens when a duty-based approach faces the pressure of extreme numbers; some will need to move on.

Iraqi and Syrian exiles and their hosts have largely rejected the contemporary international notion of the separation of the stranger/asylum seeker from the rest 
of society. These acts have a resonance and clarity with the historical context of the late Ottoman Era and its system of millet communities spread far and wide over its Arab provinces. With the collapse of the Ottoman Empire and the neocolonial imposition of British and French Mandates in the interwar years, migration, forced and voluntary, characterised the region creating widespread and large-scale networks of families, lineages, and tribes throughout. The considerations of social capital, networks, and alliances then became significant when Iraqis came to deciding the time, the place, and the route to flee their devastated country. In addition, notions of hospitality and refuge operated at the individual and community level — not by government decree. Escape and exile - though by their very nature dangerous and insecure - were more easily converted into security and asylum in the public consciousness. The granting of hospitality was seen not only as a public good but also as an act which enhanced the host's reputation. Thus asylum as an aspect of hospitality became a requirement for the individual citizen as well as the social collective. These social and ethical norms underpin the success of self-settlement and local community hosting in the Middle East.

The international humanitarian aid regime's prioritising of protection to a category of people who fit the legal definition of 'refugee' is a rigid, rights-based construction that leaves many gaps in its implementation. Those who do not wish to be categorised as legal refugees or who fail to meet the formal criteria fail to access international support. Local and regional Middle Eastern constructions of duty-based obligations to the guest, stranger, and person-in-need can, with strategic support, offer a wider range of people sanctuary and asylum sanctuary. A holistic approach which taps into the social and ethical norms of hospitality in local contexts can only improve and extend the delivery of rights-based asylum as provided by international humanitarian organisations. This we see is happening in Europe and elsewhere. In the Middle East, most states have not adopted the international standard for refugee protection. However the social reality is that karam, as a social obligation, effectively operates to provide the asylum seeker with sanctuary and refuge in an environment where international protection does not exist.

\section{REFERENCES}

Agamben, Giorgio (1998) Homo Sacer: Sovereign Power and Bare Life trans. D. Herrer-Roazen (Stanford, CA, Stanford University Press).

Argenti, Nicolas (2017), 'Post-Ottoman Topologies: The Presence of the Past in the Era of the Nation State', Social Analysis. https://doi.org/10.3167/sa.2017.610101

Chatelard, Geraldine (2010), 'What Visibility Conceals: Re-embedding Refugee Migration from Iraq', in eds Dawn Chatty, Bill Finlayson Dispossession and Forced Migration in the Middle East and North Africa (London, British Academy). 
Chatty, Dawn (1977), 'Land, Leaders and Limousines: Emir and Sheikh', Ethnography 16(4): 385-97. https://doi.org/10.2307/3773263

Chatty, Dawn (2003), “ “Operation Iraqi Freedom” and its Phantom 1 Million Iraqi Refugees', Forced Migration Review, 18: 51.

Chatty, Dawn (2010) Dispossession and Displacement in the Modern Middle East (Cambridge, Cambridge University Press). https://doi.org/10.1017/cbo9780511844812

Chatty, Dawn (2013), 'Guests and Hosts', Cairo Review, 9: 76-85.

Chatty, Dawn \& Lewando-Hundt, Gillian (eds) (2005) Children of Palestine: Experiencing Forced Migration in the Middle East (Oxford, Berghahn Books).

Chatty, Dawn et al. (2014), 'Ensuring Quality Education for Young Refugees from Syria (12-25 Years): A Mapping Exercise', Forced Migration Policy Note, Refugee Studies Centre, Oxford Department of International Development, University of Oxford.

Cohen, Robin (1994) Frontiers of Identity: The British and the Others (London and New York, Longman).

Cohen, Robin (1997) Global Diasporas: An Introduction (London, Routledge). https://doi.org/10.4324/9780203228920

Crisp, J. (2003), 'No Solutions in Sight: The Problems of Protracted Refugee Situations in Africa', Evaluation and Policy Unit Working Paper no. 75, United Nations High Commission for Refugees, Geneva.

Crisp, J. \& Slaughter, A., (2009), 'A Surrogate State? The Role of the UNHCR in Protracted Refugee Situations', New Issues in Refugee Research Paper no 168, United Nations High Commission for Refugees, Geneva.

Derrida, Jacques (2000), 'Hostipitality', Agnelaki, 5(3): 3-18.https://doi.org/10.1080/09697250020034706 Derrida, Jacques \& Dufourmantelle, Anne (2000) Of Hospitality: Anne Dufourmantelle Invites Jacques Derrida to Respond trans R. Bowlby (Stanford, CA, Stanford University Press).

ECHO (2015), 'Refugee Crisis in Europe', European Civil Protection and Humanitarian Aid Operations. Fassin, Didier (2005), 'Compassion and Repression: The Moral Economy of Immigration Policies in France', Cultural Anthropology, 20(3): 362-87. https://doi.org/10.1525/can.2005.20.3.362

Harrell-Bond, B. (1986) Imposing Aid: Emergency Assistance to Refugees (Oxford, Oxford University Press).

Herzfeld, Michael (1992) The Social Production of Indifference: Exploring the Symbolic Roots of Western Bureaucracy (Chicago, IL, University of Chicago Press).

Human Rights Watch (2004), 'Reversing Ethnic Cleansing in Northern Iraq', Human Rights Watch 16(4E).

International Crisis Group (2013), 'Blurring the Borders: Syrian Spillover Risks for Turkey', Report 225, International Crisis Group, https://www.crisisgroup.org/middle-east-north-africa/easternmediterranean/syria/blurring-borders-syrian-spillover-risks-turkey

IOM (2015)', Iraqi Returnees from Syria following the 2011 Syrian Crisis', International Organization of Migration.

Kirisci, Kemal (2013) Syrian Humanitarian Crisis: The Fundamental Difficulties Facing Turkey (Washington, DC, Brookings Institution).

Jamal, A. (2000), 'Refugee Livelihoods in Kakuma, Kenya', Evaluation and Policy Unity Working Paper no. 5, United Nations High Commission for Refugees, Geneva.

Loizos, Peter (1999), 'Ottoman Half-lives: Long Term Perspectives on Particular Forced Migrations', Journal of Refugee Studies, 12(3): 237-63.https://doi.org/10.1093/jrs/12.3.237

Long, K. (2013), 'When Refugees Stopped being Migrants: Movement, Labour and Humanitarian Protection', Migration Studies,1(1):4-26. https://doi.org/10.1093/migration/mns001

Marfleet, Philip \& Chatty, Dawn (2009), 'Iraq's Refugees-Beyond “Tolerance”, , RSC Forced Migration Policy Brief no. 4. Refugee Studies Centre, University of Oxford.

Mauss, Marcel (2016 [1925]) The Gift Expanded Edition trans. Jane Guyer (Chicago, IL., Hau Books). 
McCarthy, Justin (2001) The Ottoman Peoples and the End of Empire (London, Arnold).

Pialek, Nicholas (2008), 'Is this Really the End of the Road for Gender Mainstreaming? Getting to Grips with Gender and Institutional Change', in Can NGOs Make a Difference? The Challenge of Development Alternatives Eds A. Bebbington, S. Hickey \& D. Mitlin (London, Zed Books) 279-97.

Quataert, Donald (2000) The Ottoman Empire, 1700-1922 (Cambridge, Cambridge University Press).

Rabo, Annika (2008), 'Narrating Ethnic and Religious Heterogeneity in Contemporary Aleppo',, in 9th Mediterranean Research Meeting, Robert Schuman Centre,European University Institute, Montecatini.

Rozakou, Katerina (2012), 'The Biopolitics of Hospitality in Greece: Humanitarinasm and the Managment of Refugees', American Ethnologist, 39(3): 562-77. https://doi.org/10.1111/j.1548-1425.2012.01381.x

Shields, Sarah (2016), 'The Greek-Turkish Population Exchange: Internationally Administered Ethnic Cleansing', Middle East Research and Information Project (267). http://www.merip.org/mer/mer267/greek-turkish-population-exchange

Shryock, Andrew (2004), 'The New Jordanian Hospitality: House, Host and Guest in the Culture of Public Display', Comparative Studies in Society and History, 46(1): 35-62. https://doi.org/10.1017/S0010417504000039

Sirriyeh, Ala (2016) Inhabiting Borders, Routes Home: Youth, Gender, Asylum (London, Routledge).

Sommer-Houdeville (2017), 'Remaking Iraq: Neoliberalism and a System of Violence after the US Invsion, 2003-2011', Stockholm Studies in Sociology 66, University of Stockholm.

Syria Regional Refugee Response (2016) 'List of Partners'. http://data.unhcr.org/syrianrefugees/partnerlist.php

UNHCR (1997), 'Policy on Refugees in Urban Areas', December, United Nations High Commission for Refugees, Geneva.

UNHCR (2009,) 'Surviving in the City: A Review of UNHCR's Operation for Iraqi Refugees in Urban Areas of Jordan, Libya and Syria', Policy Development and Evaluation Service, United Nations High Commission for Refugees, Geneva.

Van Hear, Nicholas (1998) New Diasporas: The Mass Exodus, Dispersal, and Regrouping of Migrant Communities (Seattle, WA, University of Washington Press).

Vertovic, Steven (2001), 'Transnationaloism and Identity', Journal of Ethnic and Migration Studies 27(4): 573-82. https://doi.org/10.1080/13691830120090386

Wedeen, Lisa (1999) Ambiguities of Domination: Politics, Rhetoric and Symbols in Contemporary Syria (Chicago, IL, University of Chicago Press).

White, Ben, Haysom, Simone \& Davey, Eleanor (2013), 'Refugees, Host States, and Displacement in the MIddle East: An Enduring Challenge', HPN: Humanitarian Exchange Magazine, (59): 20-1.

White, Benjamin (2004) French Minorities Policy in Mandate Syria: Discourse, Domination, and Orwell's Elephant', in British Society for Middle Eastern Studies Annual Conference, London.

White, Benjamin Thomas (2011) The Emergence of Minorities in the Middle East: The Politics of Community in French Mandate Syria (Edinburgh, University of Edinburgh Press). https://doi.org/10.3366/edinburgh/9780748641871.001.0001

Note on the author: Dawn Chatty is Emeritus Professor in Anthropology and Forced Migration, former Director of the Refugee Studies Centre in the Department of International Development, and Emeritus Fellow at St Cross College, University of Oxford, UK. She is also a Fellow of the British Academy. Her research interests include: Syria and its displaced peoples, coping strategies and resilience of refugee 
youth, nomadic pastoralism and conservation, gender and development, health, illness and culture. Her recent books include: From Camel to Truck (2nd edition, White Horse Press, 2013), Dispossession and Displacement in the Modern Middle East (Cambridge University Press, 2010), Dispossession and Forced Migration in the Middle East and North Africa (ed. with Bill Finlayson, Oxford University Press, 2010), Deterritorialized Youth: Sahrawi and Afghan Refugees at the Margins of the Middle East (ed., Berghahn Books, 2010), Nomadic Societies in the Middle East and North Africa: Facing the 21 st Century (Leiden, Brill, 2006), Children of Palestine: Experiencing Forced Migration in the Middle East (ed. with Gillian Lewando-Hundt, Berghahn Books, 2005), and Conservation and Mobile Peoples: Displacement, Forced Settlement and Sustainable Development (ed. with Marcus Colchester, Berghahn Press, 2002). dawn.chatty@qeh.ox.ac.uk

To cite the article: Dawn Chatty (2017), 'The duty to be generous (karam): Alternatives to rights-based asylum in the Middle East', Journal of the British Academy, 5: 177-199.

DOI https://doi.org/10.85871/jba/005.177

This article is licensed under a

Creative Commons Attribution-NonCommercial-NoDerivs 3.0 Unported License.

Journal of the British Academy (ISSN 2052-7217) is published by

The British Academy - the national academy for the humanities and social sciences.

10-11 Carlton House Terrace, London, SW1Y 5AH

www.britishacademy.ac.uk 
